\title{
A escolha do livro didático de língua estrangeira do Programa Nacional do Livro Didático
}

\author{
Larissa Goulart da Silva \\ University of Warwick \\ goulart.larissa@hotmail.com \\ Simone Sarmento \\ Universidade Federal do Rio Grande do Sul \\ simone.sarmento@ufrgs.br
}

\section{Resumo}

Este trabalho tem por objetivo investigar os critérios utilizados pelos professores de Língua Estrangeira das escolas públicas para selecionar o livro didático (LD) do Programa Nacional do Livro Didático (PNLD). O PNLD abrange o componente curricular de Língua Estrangeira desde 2011. Estudos anteriores (SARMENTO; SILVA, 2012; 2013) investigaram aspectos relacionados ao PNLD nas escolas, sem, contudo, detalhar o processo de escolha realizado pelos professores. Acreditamos que esta pesquisa seja relevante para alguns segmentos: 1) os professores, que poderão refletir sobre sua prática; 2) as editoras, que poderão repensar a divulgação dos seus materiais; 3) o próprio PNLD como forma de acompanhar o desenvolvimento do programa nas escolas. Foram analisados questionários realizados com professores de inglês e espanhol. Concluiu-se que a maioria dos professores tem realizado uma seleção impressionista (CUNNINGSWORTH, 1995) do LD devido à falta de tempo para se dedicar a uma avaliação criteriosa e ao desconhecimento dos recursos disponíveis para auxiliar na escolha, como, por exemplo, o Guia do Livro Didático.

Palavras-chave: Livro didático. Programa Nacional do Livro Didático.

Seleção de livro didático.

\section{Abstract}

This paper aims to investigate the criteria used by foreign language teachers in public schools to choose the textbook (LD) from the National Textbook Program (PNLD). The PNLD has encompassed foreign languages since 2011. 
Previous studies (SARMENTO; SILVA, 2012; 2013) have investigated aspects related to the use of PNLD in schools; however, these studies did not investigate textbook choice. We believe this research is relevant to the: 1) teachers who will be able to reflect on their own practice; 2) publishers who may rethink the advertising of materials; 3 ) PNLD as a way to monitor the development of the program in schools. We analyzed questionnaires conducted with foreign language teachers and concluded that most teachers have chosen a textbook following an impressionistic fashion (CUNNINGSWORTH, 1995) due to lack of time for evaluation and of knowledge about the resources available to assist in their choice as, for example, the textbook guide.

Keywords: Textbook. National Program of Textbook. Textbook selection.

\section{Introdução}

Este trabalho ${ }^{1}$ é um recorte da pesquisa intitulada "O Programa Nacional do Livro Didático no cotidiano escolar da educação linguística", realizada na Universidade Federal do Rio Grande do Sul. O propósito é investigar os critérios utilizados pelos professores de Língua Estrangeira ${ }^{2}$ (LE) do Ensino Fundamental (EF) para a escolha dos Livros Didáticos (LDs) no triênio (2014-2015-2016). Foi aplicado um questionário com 16 professores em 2014. Além disso, dados de dois questionários

${ }^{1}$ Este trabalho é um recorte do TCC de Larissa Goulart da Silva (2014) intitulado A seleção do livro didático de língua estrangeira do Programa Nacional do Livro Didático. Disponível em: <http://hdl.handle.net/10183/105260>.

2 Schlatter e Garcez (2009) argumentam a favor do termo "língua adicional" no lugar de língua estrangeira devido ao acréscimo que as línguas inglesa e espanhola trazem para quem se ocupa delas e por serem línguas que muitas vezes estão a serviço da comunicação entre pessoas de diversas culturas e nacionalidades, sendo difícil definir claramente quem são os nativos ou os estrangeiros. Os autores consideram que de certa forma "essas línguas fazem parte dos recursos necessários para a cidadania contemporânea" (op cit., p. 128). Apesar de concordar com a posição dos autores, a terminologia "língua estrangeira" será mantida por ser esta utilizada em vários documentos oficiais que serão referidos ao longo deste texto. 
realizados no ano de 2011, relativos à escolha dos LDs para a primeira edição do PNLD, serão apresentados.

O PNLD é um programa do FNDE/MEC que fornece LDs gratuitamente para as escolas públicas. No ano de 2011 houve a inclusão do componente curricular de LE para o Ensino Fundamental. Em 2014, as escolas receberam os LDs relativos à segunda edição do PNLD/LEM. O LD do componente curricular de LE apresenta algumas diferenças com relação aos de outros componentes curriculares. Primeiramente, os LDs de LE são consumíveis, ${ }^{3}$ ou seja, podem ser entregues aos alunos, em segundo lugar, vêm acompanhados de um CD de áudio. A etapa da escolha pela comunidade escolar é realizada a cada três anos. Dessa forma, os professores receberão o LD escolhido em 2013 nos anos de 2014, 2015 e 2016.

No primeiro PNLD/LEM do Ensino Fundamental (EF), quatro coleções de LE foram aprovadas sendo duas de inglês e duas de espanhol. Na segunda edição foram cinco as aprovadas, três de língua inglesa e duas de língua espanhola.

$\mathrm{O}$ interesse em conhecer como os professores realizam a escolha dos LDs surgiu ao longo da realização da pesquisa, ${ }^{4}$ especialmente a partir das respostas a questionários e entrevistas (SARMENTO; SILVA, 2013). Verificou-se que 22,2\% dos professores nunca haviam utilizado um LD antes, ou seja, não tinham experiência em usá-lo. Portanto, não se sabia o que poderia ter servido como base para esses professores realizarem a escolha do LD na primeira edição em 2011.

${ }^{3}$ Os LDs dos outros componentes curriculares dos anos finais do Ensino Fundamental e do Ensino Médio são reutilizáveis, diferença que causou e ainda causa algumas questões logísticas nas escolas que acabam por influenciar aspectos pedagógicos. Essas questões foram relatadas em Sarmento e Silva (2013).

${ }^{4}$ A pesquisa intitulada "O Programa Nacional do Livro Didático no cotidiano escolar da educação linguística" iniciou no ano de 2011 com o objetivo de acompanhar a implementação do PNLD/LEM nas escolas públicas de Porto Alegre. 
Sobre a escolha, é importante salientar que o Guia do Livro Didático (GLD) (BRASIL, 2013a) é disponibilizado para auxiliar os professores no processo da seleção do LD. O GLD apresenta as coleções didáticas aprovadas pelo Programa. ${ }^{5}$ Segundo o Edital do PNLD (BRASIL, 2011, p. 13), "as coleções didáticas serão livremente escolhidas pelas escolas participantes, por meio de seu corpo docente e dirigentes, com base na análise das informações contidas no Guia de Livros Didáticos."

Contudo, Tagliani (2009) sugere que os professores nem sempre recorrem ao GLD. Consequentemente, podem escolher LDs com organizações didáticas e metodológicas diferentes daquelas adotadas pelos professores ou pelas escolas, o que poderia ser prevenido caso consultassem o GLD. Tagliani (2009) também argumenta que nem sempre os professores contam com o apoio da coordenação pedagógica da escola para auxiliá-los. Algumas escolas recebem os LDs das editoras para serem avaliados, mas em muitos desses casos o responsável apenas analisa os conteúdos programáticos da obra, não dando atenção à proposta teórico-metodológica apresentada na introdução, selecionando, assim, LDs que depois não serão adequados ao seu contexto (RAMOS, 2010). Nesse sentido, partindo das práticas verificadas por Ramos (2010) e Tagliani (2009), a questão principal deste trabalho é verificar o que está influenciando ou auxiliando os professores na seleção dos LDs que os acompanharão na sua prática em sala de aula por três anos. Utilizaremos o Ciclo de Políticas de Bowe, Ball e Gold (1992) como arcabouço teórico-metodológico.

${ }^{5}$ As coleções passam por criteriosa avaliação, que vão desde condições legais a questões relacionadas à formatação e ao conteúdo: 7.1. Constituem etapas do processo de avaliação e aprovação de coleções didáticas a triagem, a préanálise e a avaliação pedagógica" (BRASIL, 2011, p. 10). Somente as obras aprovadas irão constar no GLD e poderão, consequentemente, ser escolhidas pelos professores. 


\section{Ciclo de Políticas}

O Ciclo de Políticas (BOWE; BALL; GOLD, 1992) é uma abordagem utilizada para o entendimento e o estudo da complexidade de políticas educacionais como o PNLD. Para os autores, as políticas são séries de textos em constante mutação, cuja expressão e interpretação variam de acordo com o contexto no qual estão sendo colocadas em prática. O Ciclo, assim, permite uma análise crítica de programas educacionais desde sua formulação até seu contexto de prática. De acordo com Alferes e Mainardes (2012, p. 6),

O Ciclo de Políticas destaca a natureza complexa $e$ controversa da política educacional, enfatiza os processos micropolíticos e a ação dos profissionais que lidam com as políticas no nível local e indica a necessidade de se articularem os processos macro e micro na análise de políticas educacionais.

De acordo com Mainardes (2006, p. 57), o contexto macro de uma política preocupa-se "com a análise de questões mais amplas (por exemplo, o Estado e suas relações com o capital, as relações das respostas locais com a agenda do Estado, etc.)", enquanto o contexto micro se preocupa com a "focalização de práticas cotidianas" (MAINARDES, 2006, p. $58)$.

A abordagem do Ciclo de Políticas é profícua para a análise do PNLD, uma vez que propõe o estudo da política educacional levando em conta seus diferentes contextos, sem propor uma linearidade, pois os contextos "estão interrelacionados, não têm uma dimensão temporal ou sequencial e não são etapas lineares" (MAINARDES, 2006, p. 28). O autor apresenta os cinco contextos do Ciclo de Políticas que poderiam ser representados por meio da Figura 1. 


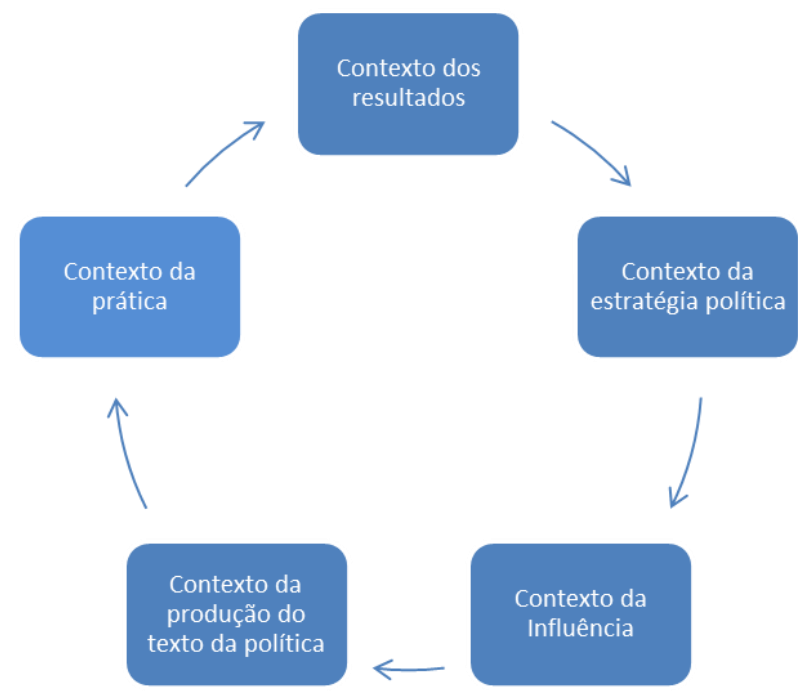

Figura 1. Ciclo de Políticas em 1994

Bowe, Ball e Gold (1992) defendem que estudar separadamente a geração da implementação de uma política reforça as controversas ideias de hierarquia e linearidade estanques dos contextos e de que o texto legislativo de uma política seria a própria política. Conforme os autores, a legislação é apenas um dos aspectos do processo contínuo em que o "lócus do poder muda também constantemente" (BOWE BALL; GOLD, 1992, p. 13). Dessa forma, advogam para a análise de políticas como processos com diferentes produções de sentido e interpretações que relacionam os textos da política com sua prática. Além disso, entendemos também que há, por exemplo, vários contextos de prática em cada política, e que para

${ }^{6}$ Original: Loci of power are constantly shifting. 
cada microprocesso há um ciclo próprio, interdependente dos outros microprocessos da mesma política.

O PNLD possui assim vários microprocessos, sendo a escolha do LD pelos professores um deles. O principal (mas não o único) texto legislativo desta etapa é o GLD (BRASIL, 2013), enquanto o contexto da prática constitui-se nos procedimentos de escolha do LD levado a cabo (ou não) pelos professores. Cabe ressaltar que segundo Bowe, Ball e Gold (1992) e Mainardes (2006) é precisamente no(s) contexto(s) da prática que a política está sujeita à interpretação e à recriação pelos atores sociais e onde produz mais efeitos e consequências, exigindo, assim, um olhar mais aguçado dos pesquisadores.

\section{Escolha do livro didático}

Cunningsworth (1995, p. 10) aponta dois tipos de avaliação de um LD: avaliação impressionista e avaliação profunda. A primeira consiste em "formar rapidamente uma impressão sobre o LD, realizando uma observação rápida do livro, adquirindo uma visão global das suas possibilidades de uso, seus pontos fortes e fracos, notando os recursos mais significativos que se destacam". ${ }^{7}$ A avaliação profunda é mais "detalhada na sua abordagem e segue sua própria agenda" (CUNNINGSWORTH, 1995, p. 11). Em uma análise profunda, "é útil selecionar uma ou duas unidades do LD e analisá-las em detalhe"9 (CUNNINGSWORTH, 1995, p. 11).

${ }^{7}$ Original: Form a general impression of a coursebook fairly quickly, just by looking through it and getting an overview of its possibilities and its strengths and weaknesses, noting significant features which stand out.

${ }^{8}$ Original: In-depth evaluation which is more penetrating in its approach and has its own agenda.

${ }^{9}$ Original: It is useful to pick out one or two units of a coursebook and analyse them in detail. 
Cunningsworth (1995, p. 14) propõe que antes de avaliar os LDs os professores criem uma lista de critérios analisando as necessidades específicas do ambiente em que o LD será utilizado. Esses critérios devem refletir "primeiramente os objetivos do seu programa de ensino e em segundo lugar analisar o contexto de ensino e aprendizagem em que o material será usado". ${ }^{10}$

Tomlinson (2003, p. 5) também propõe que a avaliação do LD se dê de forma "rigorosa, sistemática e baseada em princípios", utilizando dois tipos de avaliação: a análise e a seleção. Tomlinson (2012, p. 149) apresenta a análise como "a observância de critérios superficiais" e a seleção como a observância "do LD de forma mais criteriosa". Os tipos de avaliação propostos por Tomlinson assemelham-se à avaliação apresentada por Cunningsworth, no qual a "análise" (TOMLINSOM, 2012) seria similar à "avaliação impressionista" (CUNNINGSWORTH, 1995), assim como a "seleção" assemelhar-se-ia à "avaliação profunda".

Com relação à avaliação dos LDs no PNLD, o GLD de LE (BRASIL, 2013a) apresenta a ficha de avaliação utilizada pela comissão avaliadora do programa. Esta ficha contém alguns critérios que podem auxiliar os professores na seleção da coleção didática mais apropriada ao seu contexto, ou seja, na realização de uma avaliação profunda (CUNNINGSWORTH, 1995).

Tagliani (2009, p. 315), discutindo a escolha do LD de língua portuguesa, conclui que uma das dificuldades para a seleção dos LDs nas escolas públicas é a falta de tempo para reuniões:

Percebemos, com base nos aspectos discutidos, que a escolha do material didático pelo professor de língua

${ }^{10}$ Original: Firstly identify the aims and objectives of your teaching programme and secondly analyse the learning/teaching situation in which the material will be used. 
portuguesa envolve bem mais do que uma ou duas reuniões para discussão; é um percurso bastante longo a ser percorrido - o próprio guia dá orientações nesse sentido, o que, talvez, não se encaixe no ritmo de trabalho da maioria dos professores da rede pública, que acumulam horas de trabalho em dois e até três turnos diários.(Faltam as referências?)

Ramos (2010) e Batista (2003) também argumentam que a falta de tempo para a escolha da coleção é um dos fatores a prejudicar o PNLD. O objetivo desta seção foi apresentar diferentes visões relativas à avaliação e à seleção de LDs apresentadas na literatura e em outras pesquisas sobre o PNLD.

\section{Procedimentos metodológicos}

Foram aplicados três questionários a professores de LE de escolas públicas: dois em 2011, no primeiro ano do PNLD/LEM, e um em 2014. O primeiro questionário foi enviado por correspondência e por e-mail para todos os professores de LE das escolas municipais ${ }^{11}$ de Porto Alegre em março de 2011, com 27 respondentes, sendo oito professores de Espanhol e 19 professores de inglês. $\mathrm{O}$ segundo questionário foi enviado por $e$ mail e apenas para os professores de língua inglesa que desejaram continuar na pesquisa. Ao total, nove professores responderam. O terceiro questionário foi aplicado em 2014 a professores de língua inglesa que estavam participando do curso "Formação continuada para professores de inglês como língua adicional", oferecido pelo Instituto de Letras da UFRGS. Este questionário também foi enviado por e-mail para os professores que haviam participado da pesquisa anteriormente. Ao total 16

11 Enviamos os questionários para as escolas municipais, pois contávamos com o apoio da Assessoria de Línguas Adicionais da Secretaria Municipal de Educação. 
A escolha do livro didático de língua estrangeira...

professores de língua inglesa responderam a este último questionário. Os professores são apresentados conforme os seguintes códigos. ${ }^{12}$

Quadro 1. Códigos dos professores

\begin{tabular}{|c|c|}
\hline $1^{\circ}$ questionário & $\begin{array}{r}\mathrm{P}-\text { professor; } \mathrm{I}-\text { inglês; E- espanhol; } \\
\text { número do professor. (ex. PI10) }\end{array}$ \\
\hline $2^{\text {o }}$ questionário & $\mathrm{P}-$ professor; número do professor. (ex. P10) \\
\hline $3^{\text {o }}$ questionário & $\begin{array}{r}\mathrm{P}-\text { professor; } 3-\text { terceiro questionário; } \\
\text { número do professor. (ex. P310) }\end{array}$ \\
\hline
\end{tabular}

Conforme apresentado anteriormente, o objetivo deste trabalho é investigar os critérios utilizados pelos professores de LE na seleção do LD do PNLD/LEM do Ensino Fundamental. Para esta investigação são propostas as seguintes perguntas de pesquisa:

a) Os professores fazem uso do GLD para a escolha do LD? Se sim, de que forma esse uso se dá? Se não, outros elementos os auxiliam a escolher o LD?

b) Os professores participam de reuniões com auxílio da coordenação pedagógica para a escolha do LD?

c) A experiência de já ter usado o LD do PNLD/LEM de 2011 contribuiu de alguma forma para a seleção do PNLD/LEM 2014 ?

d) Os professores têm acesso aos LDs para análise? Se sim, como esta ocorre?

${ }^{12}$ Com base no código, o PI20 é o $20^{\circ}$ professor de inglês que respondeu ao questionário. Como os professores respondentes não são os mesmos em cada questionário, os números não se repetem. 
O resultado desta investigação poderá auxiliar os professores a refletirem sobre sua prática na escolha do LD, considerando que poderá afetar sua prática de sala de aula por três anos. Também poderá contribuir para que as editoras revejam a divulgação dos LDs aprovados pelo PNLD. Ademais, os resultados contribuem para o próprio PNLD ao apresentar dados sobre como está ocorrendo a escolha do LD, de forma que o programa possa, assim, reprogramar a produção e a divulgação do GLD com base no ponto de vista dos professores em consideração.

\section{A primeira edição do PNLD-LEM/2011}

Nesta seção serão apresentados dados relativos à primeira edição do PNLD/LEM (SARMENTO; SILVA, 2012; 2013). O objetivo é discutir apenas as respostas dos questionários realizados em 2011 relativas à escolha do LD. No primeiro questionário $^{13}(2011 / 1)$ havia apenas uma pergunta relativa à escolha do LD:

3 - Você participou da escolha da coleção?

( ) Sim ( ) Não. Em caso negativo, você sabe como foi feita a escolha? Em caso positivo, quais critérios direcionaram a escolha?

13 O objetivo dos questionários realizados em 2011 não eram única e exclusivamente relacionados a como os LDs haviam sido escolhidos. Para maiores detalhes, ver Sarmento e Silva, 2013 e 2014. 
A escolha do livro didático de língua estrangeira...

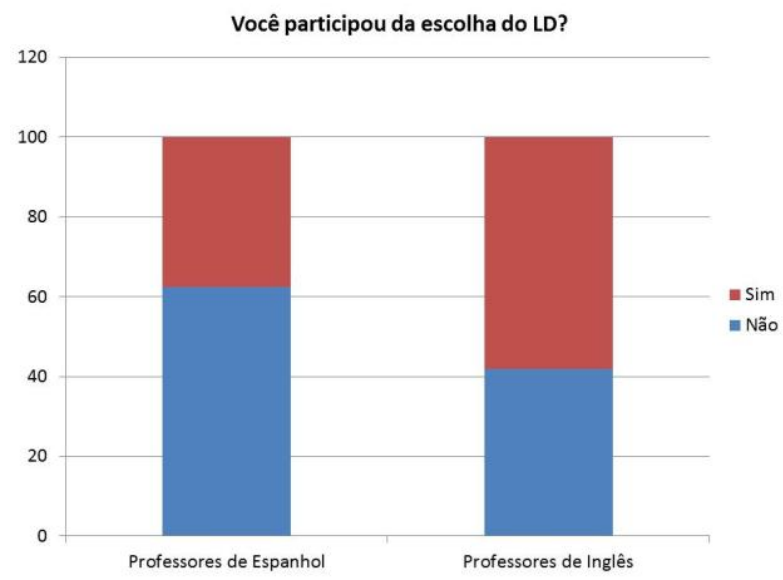

Figura 2. Participação na escolha do LD.

Cinco (62,5\%) professores do espanhol (entre oito) não participaram da escolha do LD e também não sabiam como a escolha havia ocorrido. Oito (42\%) professores de inglês (entre 19) não participaram da escolha do LD. Entre estes, três afirmaram conhecer os critérios utilizados para a escolha. As respostas encontram-se no Quadro 2.

Quadro 2. Professores que não participaram da escolha

\begin{tabular}{|l|l|}
\hline \multirow{2}{*}{$\begin{array}{l}\text { Professores } \\
\text { de inglês que } \\
\text { não } \\
\text { participaram } \\
\text { da escolha }\end{array}$} & Discussão entre professores. (PI13) \\
\cline { 2 - 2 } & $\begin{array}{l}\text { Foram entregues os dois livros para a professora de inglês } \\
\text { que não está mais na escola. (PI7) }\end{array}$ \\
\hline
\end{tabular}


No Quadro 3 são apresentados os critérios utilizados pelos professores de inglês e espanhol que afirmaram ter participado da primeira seleção (13 entre 26).

Quadro 3. Professores que participaram da escolha do LD

\begin{tabular}{|c|c|c|}
\hline \multirow{8}{*}{$\begin{array}{l}\text { Professores que } \\
\text { participaram da } \\
\text { escolha }\end{array}$} & \multirow{4}{*}{$\begin{array}{l}\text { Questões } \\
\text { visuais }\end{array}$} & $\begin{array}{l}\text { Análise comparativa dos livros } \\
\text { oferecidos, tendo observado pouca } \\
\text { diferença entre estes. Assim, o que mais } \\
\text { influenciou foi a questão estética. (PI3) }\end{array}$ \\
\hline & & $\begin{array}{l}\text { Aspectos visuais: gravuras, cores. } \\
\text { Aspectos gramaticais: conteúdos bem } \\
\text { organizados em termos de complexidade. } \\
\text { Aspectos de compreensão oral e } \\
\text { exercícios orais: CD incluso. (PI15) }\end{array}$ \\
\hline & & $\begin{array}{l}\text { Conteúdo adequado para a série; tipos de } \\
\text { atividades; ilustrações; apresentação do } \\
\text { material. (PE19) }\end{array}$ \\
\hline & & $\begin{array}{l}\text { Material didático bem elaborado, bonito, } \\
\text { colorido, interessante, textos de muitos } \\
\text { autores hispano-americanos e muito da } \\
\text { cultura hispano-americana também. } \\
\text { (PE49) }\end{array}$ \\
\hline & \multirow{3}{*}{$\begin{array}{l}\text { Relevância dos } \\
\text { conteúdos }\end{array}$} & $\begin{array}{l}\text { Boa quantidade de "listening". Critério } \\
\text { que levasse em conta a realidade e os } \\
\text { interesses dos alunos da escola. Os } \\
\text { alunos adoraram o livro. (PI5) }\end{array}$ \\
\hline & & $\begin{array}{l}\text { Relevância dos assuntos tratados no } \\
\text { livro; relevância dos conteúdos; } \\
\text { apresentação; conteúdo disponível em } \\
\text { áudio; qualidades dos textos do livro. } \\
\text { (PI10) }\end{array}$ \\
\hline & & $\begin{array}{l}\text { Como os alunos do } 3^{\circ} \text { ciclo têm uma } \\
\text { única professora no diurno e nem todos } \\
\text { os alunos cursam inglês, a professora } \\
\text { escolheu o livro que mais bem se } \\
\text { enquadrasse à proposta de trabalho: } \\
\text { atividades contextualizadas. (PI12) }\end{array}$ \\
\hline & Gramática & $\begin{array}{l}\text { Tipos de exercícios e } \\
\text { gramatical. (PI8) }\end{array}$ \\
\hline
\end{tabular}


A escolha do livro didático de língua estrangeira...

\begin{tabular}{|l|l|l|}
\hline \multirow{4}{*}{$\begin{array}{l}\text { LD mais } \\
\text { adequado à } \\
\text { escola }\end{array}$} & $\begin{array}{l}\text { Escolhemos a coleção com mais textos, } \\
\text { pois sabíamos que os livros seriam } \\
\text { usados em aula e que os alunos não os } \\
\text { receberiam individualmente. (PE14) }\end{array}$ \\
& $\begin{array}{l}\text { Procuramos uma coleção que abrangesse } \\
\text { as quatro habilidades e fosse o mais } \\
\text { acessível à realidade do aluno. (PI20) }\end{array}$ \\
\cline { 2 - 3 } & $\begin{array}{l}\text { O que mais bem se adequava ao plano } \\
\text { anual para cada nível. (PI17) }\end{array}$ \\
\cline { 2 - 3 } & Énica opção & Énica opção de escolha. (PI18) \\
\cline { 2 - 3 } & Única opção de escolha. (PI19) \\
\hline
\end{tabular}

O segundo questionário $(2011 / 2)$, respondido somente por professores de inglês (nove ao total), contava com duas perguntas relevantes para o tema deste trabalho, que serão apresentadas a seguir. A primeira é:

2 - Você já tinha a experiência de utilizar um livro didático em aulas de inglês anteriormente?

( ) $\operatorname{Sim}$ ( ) Não

Onde:

( ) Nesta mesma escola.

( ) Em outras escolas públicas.

( ) Em escola particular.

( ) Em curso de idioma.

( ) Outro. 


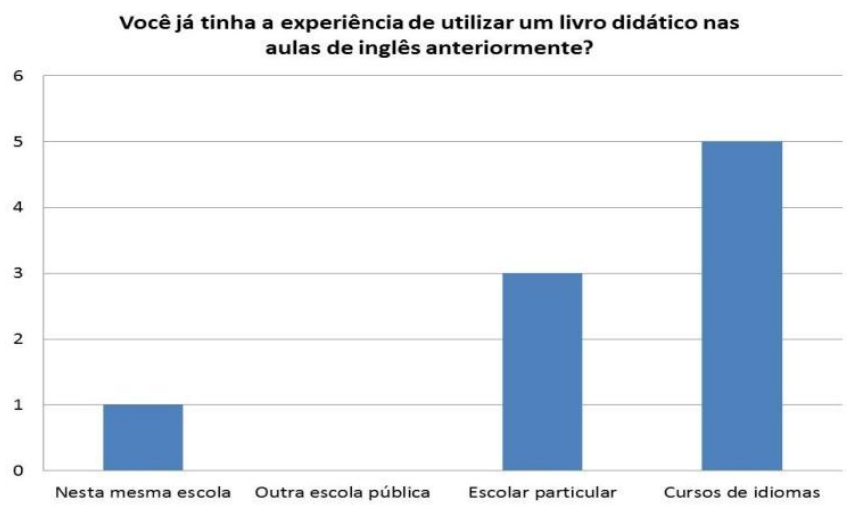

Figura 3. Experiência com um LD

Apenas um $(11,1 \%)$ professor já havia trabalhado com LD na mesma escola antes. Contudo, sete $(77,7 \%)$ tinham a experiência de trabalhar com LD antes, sendo quatro $(44,4 \%) \mathrm{em}$ cursos de idiomas, dois $(22,2 \%)$ em escolas privadas e um $(11,1 \%)$ em cursos de idiomas e escolas privadas. Conforme esses dados, apenas duas professoras (22,2\%) não possuíam qualquer experiência prévia em trabalhar com LD.

A próxima pergunta relacionada às perguntas de pesquisa deste trabalho é:

10 - Como você avaliaria o livro até este momento?

( ) Adequado ao seu contexto de ensino.

( ) Não adequado ao seu contexto de ensino.

( ) Parcialmente adequado ao seu contexto de ensino. 


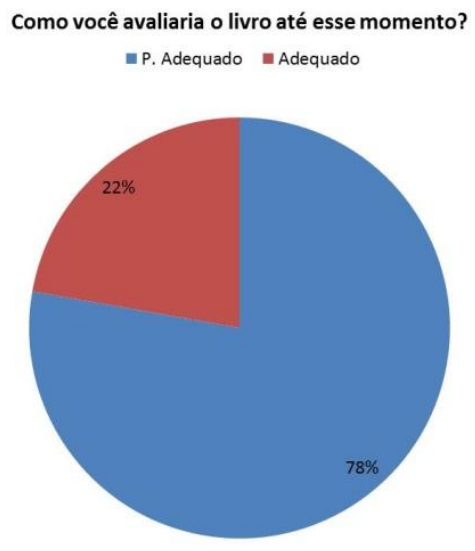

Figura 4. Avaliação do LD

Nenhum professor considerou o LD inadequado para seu contexto, dois $(22,2 \%)$ professores consideraram o LD adequado, e os outros sete $(77,7 \%)$, parcialmente adequado.

Verificando as respostas aos questionários até então apresentados, observou-se que P13, que não participou da seleção, mencionou que aconteceram reuniões entre os professores para discussão acerca da escolha do LD exatamente como sugerido pelo GLD (BRASIL, 2013, p. 6):

\begin{abstract}
Professor/professora, como você bem sabe, a responsabilidade da seleção do livro didático de língua estrangeira requer da equipe envolvida a compreensão de que a escolha implica compromisso didático-pedagógico. Esse compromisso, ao levar em consideração as circunstâncias histórico-sociais do seu grupo, exige cuidado nas discussões, a fim de que não se trate como homogêneo e simples aquilo que é naturalmente heterogêneo e complexo.
\end{abstract}

Em contrapartida, os respondentes que afirmaram ter participado da seleção não mencionam reuniões. Isso pode ter se dado pela forma como a pergunta foi formulada. Os respondentes 
podem ter priorizado outros aspectos acerca da escolha da coleção, que, nas suas opiniões, pareciam mais relevantes.

Para os professores que manifestaram ter participado da escolha, os principais critérios apresentados foram (Quadro 3): design gráfico, questões gramaticais, relevância dos conteúdos apresentados na coleção e adequação da coleção ao contexto. Esses critérios foram muito semelhantes aos apresentados por Ramos (2010, p. 62), nos quais os professores investigados apontam como critérios para a seleção do LD "textos, exercícios de vocabulário e gramática, ilustrações".

As respostas desses dois grupos de professores (desta pesquisa e de RAMOS, 2010) podem apontar critérios referentes a uma seleção impressionista, ou seja, uma seleção realizada "folheando o LD rapidamente para ver os conteúdos, figuras, etc." (RAMOS, 2010, p. 60) ou "só de olhar através do LD e obter uma visão geral de suas possibilidades e seus pontos fortes e fracos" (CUNNINGSWORTH, 1995, p. 10). ${ }^{14}$ Ainda como resposta a essa pergunta, dois professores (PI18 e PI19) declararam ser a única coleção disponível, o que indica que talvez não tenham acessado o GLD (BRASIL, 2010), no qual constavam resenhas de duas coleções para cada LE e que, nesta primeira edição, possuía versões digital e impressa. Efetivamente, não há qualquer menção ao GLD, nem mesmo como auxílio para a escolha. Além disso, é possível perceber que alguns professores tiveram acesso ao LD, pois avaliaram questões como design gráfico, o que não seria possível apenas fazendo uso do GLD. P17 deixa claro que os professores da sua escola fizeram a seleção com base no LD: "Foram entregues os dois livros". Assim, o material que mais parece ter auxiliado os professores nesta seleção foi o material de divulgação enviado pelas editoras, que inclui exemplares dos LDs.

\footnotetext{
14 Original: Just by looking through it and getting an overview of its possibilities and its strengths and weaknesses.
} 
Nesse sentido, os diversos atores sociais envolvidos em colocar a política em prática estão reinterpretando o que é proposto pelo texto da política (BOWE; BALL; GOLD, 1992), pois, por um lado, editoras não parecem estar seguras com relação à eficácia do GLD e estão enviando os materiais diretamente para as escolas. Por outro lado, os professores nem parecem conhecer o GLD, ou, se o conhecem, também não o estão destacando como relevante no processo de escolha do LD e estão utilizando outros recursos para realizar a seleção.

As respostas ao segundo questionário dizem respeito à experiência com LDs. A maioria $(77,7 \%)$ dos professores confirmou possuir alguma experiência com o uso de LD, mas somente um confirmou ter tido esse tipo de experiência em escola pública. Cabe salientar que nos outros contextos de ensino (da rede privada), apesar de haver um uso consagrado de LDs, não é comum que o professor participe da escolha do LD, ficando geralmente incumbido da coordenação.

Por fim, a última pergunta apresentada diz respeito à opinião dos professores acerca do LD após quase um ano de uso (final de 2011). Todos julgaram o livro adequado ou parcialmente adequado. Supomos que suas visões podem tê-los influenciado na escolha do LD de LE da segunda edição. Como aponta Tagliani (2009, p. 308), avaliar o LD em uso pode colaborar com a seleção do próximo LD: em "uma escola resolveram (os professores) não escolher o autor do LD do ano anterior por considerarem que a obra usada até então não estava satisfazendo suas necessidades pedagógicas" (TAGLIANI, 2009, p. 315). Enfim, com base na análise dos dados de 2011 pode-se argumentar que os LDs selecionados pelo MEC parecem ser adequados para a realidade brasileira, pois nenhum professor sugeriu que o LD seja inadequado para seu contexto de ensino. $\mathrm{Na}$ seção seguinte serão apresentados os dados relativos à seleção da segunda edição do PNLD/LEM. 


\section{A segunda edição do PNLD-LEM/2014}

O objetivo deste questionário, aplicado em março de 2014, era investigar detalhadamente a escolha do LD para o PNLD/LEM 2014. Ao total, 16 professores de língua inglesa participantes de um curso de formação na universidade federal responderam.

1. Há quantos anos você dá aula de inglês nesta escola?

( ) Menos de um ano.

( ) Um ano.

( ) Dois anos.

( ) Três anos.

( ) Quatro anos.

( ) Mais de quatro anos.

Há quantos anos você dá aula de Inglês nesta escola?

Mais de quatro anos

Menos de um ano

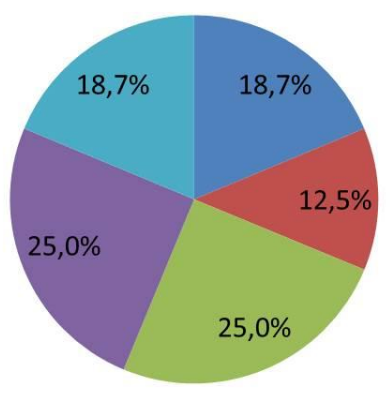

Figura 5. Tempo de atuação na escola 
De acordo com as respostas, a maior parte dos professores atua na mesma escola há mais de um ano. Desse modo, estavam presentes na escola no período relativo à escolha do PNLD (segundo semestre de 2013), ainda que nem todos tenham participado ativamente do processo. Além disso, o fato de os professores estarem na escola há pelo menos um ano indica que possivelmente tiveram algum contato com o LD da primeira edição do PNLD/LEM.

2. Você está utilizando o LD do PNLD?

( ) Sim. ( ) Não.

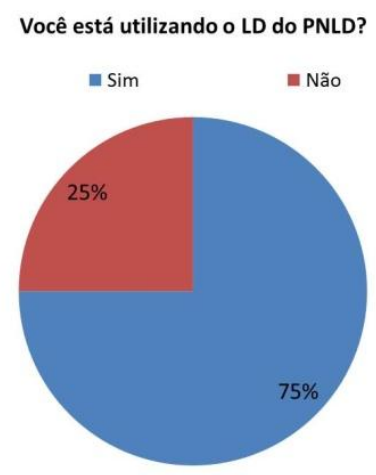

Figura 6. Uso do LD do PNLD

De acordo com as respostas, a maior parte dos professores está utilizando o LD. Aqueles que não o estão utilizando justificaram o não uso por não estarem de acordo com o LD específico que sua escola recebeu.

3. Você já havia utilizado algum LD antes? (os professores podiam marcar mais de uma opção). 
( ) Na escola privada.

( ) Em cursos de idiomas.

( ) Outros LDs na escola pública.

( ) Outro.

Você já havia utilizado algum LD antes?

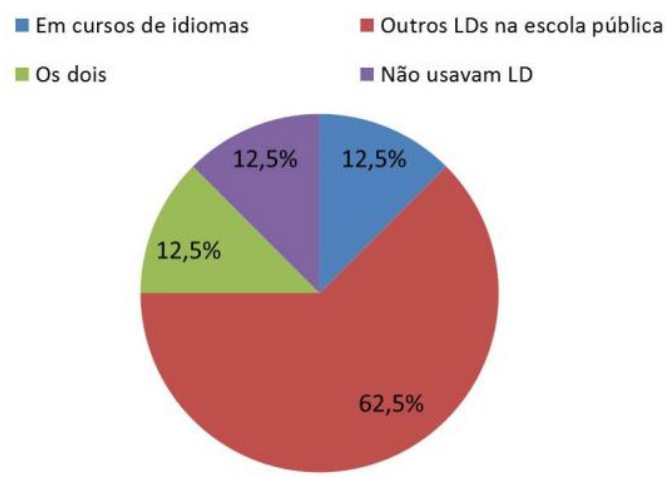

Figura 7. Experiência com um $L D$

Neste caso prevalecem os professores que haviam utilizado outros LDs em escolas públicas.

4. Você participou da escolha do LD de língua estrangeira do PNLD? Se não, quem escolheu?

( ) Outros professores.

( ) O/a coordenador(a) pedagógico(a).

( ) Outros. 


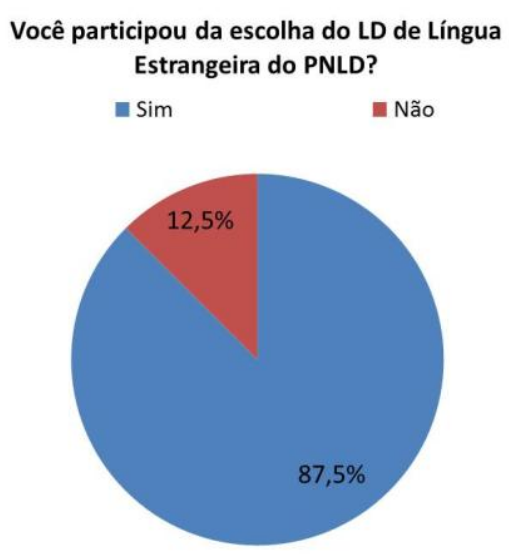

Figura 8. Participação na escolha do LD

Apenas dois professores (12,5\%) não participaram da escolha do LD: um afirma não saber quem a realizou, e outro diz que colegas realizaram a escolha. Há ainda o caso de um professor que realizou a escolha, mas a vice-diretora da sua escola optou por outra coleção.

Os professores, preponderantemente, declaram ter participado da seleção do LD, como sugerido pelo GLD. Um professor não esclarece por que não participou, apesar de já estar na escola. P31 opina que o processo de escolha do LD em sua escola não foi transparente, pois, apesar de ter participado da escolha do LD, não recebeu os LDs escolhidos. Contudo, isso pode ter ocorrido em razão de diversos fatores inerentes ao Programa - disponibilidade da editora, negociações de valores... - e não necessariamente devido à falta de transparência da escola. As orientações para a escolha do PNLD alertam para este ponto:

5.3. Para cada componente curricular, deverão ser escolhidas duas obras (grifo nosso), em $1^{\underline{a}}$ e $2^{\underline{a}}$ opção, de 
editoras diferentes. [...] Caso não seja possível a aquisição dos livros referentes à editora de $1^{a}$ opção, serão tentados os livros da $2^{\underline{a}}$ opção (BRASIL, 2013b, p. 1).

Ressaltamos o desconhecimento de algumas regras do PNLD pelos envolvidos. Seria interessante este aviso constar também no GLD, e não somente no documento de orientação para a escolha, visto que o GLD é o principal documento oficial direcionado aos.

5. Se você participou da escolha do LD e já o havia utilizado antes, você acredita que a experiência de ter usado um LD antes influencia na escolha?

\section{( ) Sim. ( ) Não.}

Todos os professores que já haviam utilizado o LD concordam que esta experiência influencia na escolha. No Quadro 4 são listados os argumentos apresentados pelos professores como justificativa.

Quadro 4. Influência de já ter usado o LD antes

\begin{tabular}{|l|l|}
\hline \multirow{2}{*}{$\begin{array}{l}\text { Comparação } \\
\text { com o } \\
\text { PNLD/LEM } \\
\text { passado. }\end{array}$} & $\begin{array}{l}\text { Fui bem criterioso em escolher o livro atual, pois o livro } \\
\text { que era usado na escola quando cheguei era muito fraco. } \\
\text { (P38) }\end{array}$ \\
\cline { 2 - 2 } & $\begin{array}{l}\text { O livro do PLDN anterior era muito ruim, o que fez com } \\
\text { que eu tivesse desinteresse em escolher a coleção para este } \\
\text { ano. (P33) }\end{array}$ \\
\hline \multirow{2}{*}{$\begin{array}{l}\text { Comparação } \\
\text { das atividades e } \\
\text { do conteúdo } \\
\text { dos LDs }\end{array}$} & $\begin{array}{l}\text { Geralmente os conteúdos são parecidos em diferentes LDs, } \\
\text { e é mais fácil escolher o que mais se parece com os planos } \\
\text { de estudo (nem sempre ocorre). (P34) }\end{array}$ \\
\cline { 2 - 2 } & $\begin{array}{l}\text { É possível ter um comparativo de atividade possivelmente } \\
\text { testada com as do LD. (P36) }\end{array}$ \\
\cline { 2 - 2 }
\end{tabular}




\begin{tabular}{|c|c|}
\hline & $\begin{array}{l}\text { O professor que já utilizou um livro didático sabe o que } \\
\text { poderia melhorar e o que poderia ser substituído no } \\
\text { material. (P39) }\end{array}$ \\
\hline & $\begin{array}{l}\text { Através da análise do que deu certo e do que não deu; } \\
\text { extensão das atividades; adequação de textos e tarefas do } \\
\text { livro anterior. (P315) }\end{array}$ \\
\hline & $\begin{array}{l}\text { Ajuda a decidir qual das opções dadas é a melhor. Aquele } \\
\text { que oferece melhores textos e atividades. (P310) }\end{array}$ \\
\hline & $\begin{array}{l}\text { É possível comparar atividades propostas nos diferentes } \\
\text { livros. (P311) }\end{array}$ \\
\hline & Como base comparativa. (P312) \\
\hline & É uma forma de comparação. (P314) \\
\hline \multirow[t]{4}{*}{ Outros } & $\begin{array}{l}\text { A cada material selecionado e utilizado ficamos mais } \\
\text { críticos e conscientes na hora de escolher o próximo. Vários } \\
\text { fatores são levados em conta, primeiramente a reação dos } \\
\text { alunos à possibilidade de possuírem um material próprio e } \\
\text { individual, seguido pelo impacto visual (se o material é ou } \\
\text { não atraente para eles), se possui um bom fio condutor e } \\
\text { como cada informação é apresentada e trabalhada (se o } \\
\text { material é "aberto" e estimula ligações com a realidade } \\
\text { atual ou é "engessado"). Infelizmente as opções oferecidas } \\
\text { ainda são extremamente reduzidas e não permitem grandes } \\
\text { exigências, mas sabemos que é apenas um início. (P31) }\end{array}$ \\
\hline & Saber os pontos negativos e positivos do material. (P316) \\
\hline & $\begin{array}{l}\text { No conteúdo abordado layout do livro, experiência de usar } \\
\text { o livro. (P313) }\end{array}$ \\
\hline & $\begin{array}{l}\text { Prévio conhecimento do outro LD para ter um parâmetro. } \\
\text { (P37) }\end{array}$ \\
\hline
\end{tabular}

Os professores expressam diferentes tipos de influência. Por exemplo, P38 e P33 relatam o mesmo problema com o LD anterior - "um livro muito ruim ano passado" -, com consequências diferentes: P38 afirma ter sido mais criterioso na escolha para 2014 com o objetivo de não incorrer no mesmo problema, enquanto P33 perdeu o interesse de realizar a escolha 
do LD acreditando que todos os LDs fossem ruins. Alguns professores (P36, P39, P315, P310 e P311) dão mais detalhes sobre a comparação entre dois livros, afirmando que compararam as atividades e/ou os conteúdos entre um LD e outro. P36 e P315 mencionam saber que atividades funcionam com seus alunos ou não baseados na experiência de uso com o LD anterior. P312 e P314 falam somente em comparação, sem definir que aspectos foram comparados.

6. Se você participou da escolha do LD, o que auxiliou na sua escolha?

( ) Análise do LD.

( ) Consulta do GLD.

( ) Discussão com outros professores.

( ) Outros.

Se você participou da escolha do LD, o que auxiliou na sua escolha?

— Análise do LD — Discussão com outros professores — Não responderam

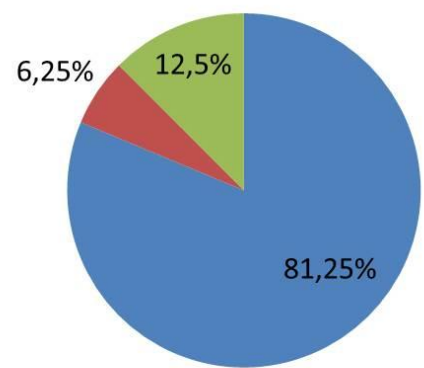

Figura 9. Fatores influenciadores da escolha do LD

Um professor afirmou ter sido auxiliado por colegas, enquanto os outros apontam ter realizado análise dos LDs 
enviado pelas editoras. Apesar de os professores poderem escolher mais de uma opção nesta pergunta, todos eles marcaram apenas uma. Semelhantemente aos dados de 2011, os professores não marcaram a alternativa que citava o GLD. Nesse sentido, Alvim (2009) aponta para o fato de que as resenhas do GLD são um produto de diversas leituras do $\mathrm{LD}$, pois primeiro os avaliadores fazem a ficha de avaliação relativa ao $\mathrm{LD}$, ao passo que a resenha de cada obra é escrita por outra pessoa como produto dessa ficha de avaliação. Ou seja, as resenhas poderiam ser um fator a mais a ajudar na escolha. Não foi perguntado aos professores por que não consultaram o GLD, mas seria interessante conhecermos os motivos, que podem ser falta de tempo, desconhecimento do Guia, entre outros.

7. Você teve acesso aos LDs para análise?

( ) Sim.

( ) Não.

( ) Algumas coleções, não todas.

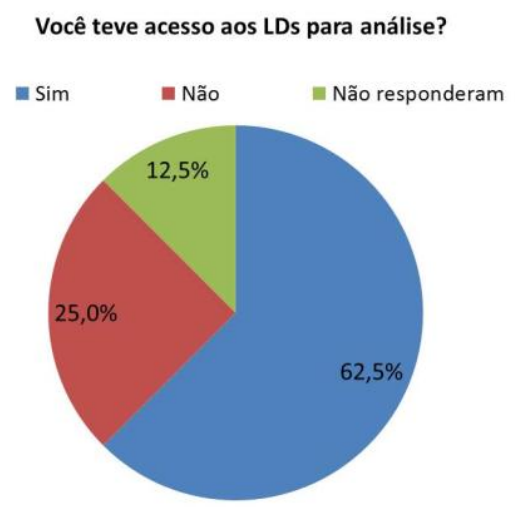

Figura 10. Acesso ao LD para análise 
O motivo desta pergunta é a resposta dada por PI18 e PI19 ao primeiro questionário (2011/1), pois ambos os professores afirmam ter escolhido determinada coleção por ser "a única opção". Apenas uma coleção deve ter sido enviada à escola, levando-os a acreditar ser a única opção. Quatro professores afirmam não ter recebido todas as coleções, coincidentemente todos de escolas fora de Porto Alegre, o que pode ter influenciado no não envio de todas as obras devido ao difícil acesso. Além disso, essas escolas não concentram tantos alunos quanto as da capital. Apesar de ser autorizado no Edital de Convocação para o Processo de Inscrição e Avaliação de Coleções Didáticas para o PNLD, o envio de LDs para as escolas não consta nos textos como obrigação das editoras de enviar os LDs de divulgação diretamente para as escolas do Brasil.

8. Se teve acesso, de que forma?

( ) As editoras enviaram.

( ) O/a coordenador(a) pedagógico entrou em contato com as editoras para que o LD fosse enviado. ( ) Outro.

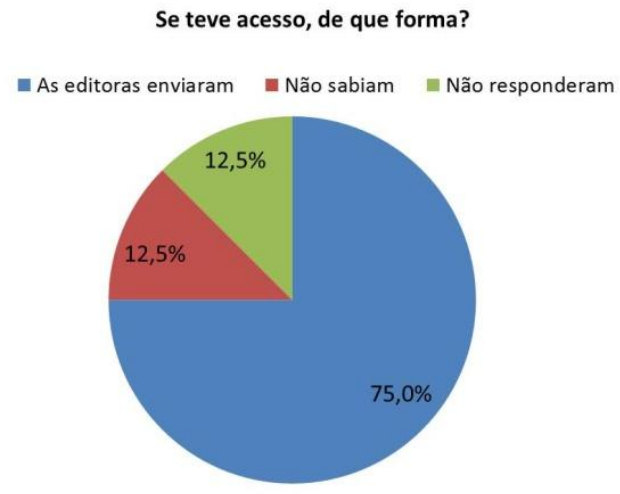

Figura 11. Tipo de acesso ao LD 
O interesse desta pergunta é verificar como os professores têm acesso ao livro. Podemos observar que na maior parte dos casos são as editoras que procuram as escolas, pois 12 professores afirmam ter recebido os LDs diretamente das editoras, enquanto dois professores não sabiam como os livros haviam chegado à escola. Em alguns casos, o material de divulgação (e não o próprio livro) das editoras passa a impressão de ser uma publicação oficial do PNLD (CASSIANO, 2007), como pode ser visto na Figura 12. Este catálogo de uma grande editora para divulgar os seus LDs selecionados para o PNLD/2004 pode facilmente ser confundido com o GLD oficial (que desde 2014 existe apenas na versão eletrônica), podendo passar a falsa impressão de que somente aqueles livros estão disponíveis.

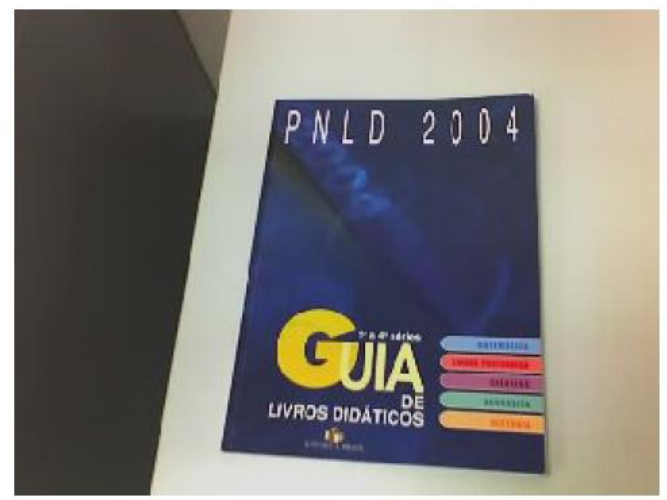

Figura 12. Material de divulgação de uma editora

Fonte: Cassian (2007, p. 74)

9. Se você fez uma análise do LD, que critérios você observou? (os professores podiam marcar mais de uma opção) 
( ) O projeto gráfico (figuras, cores, organização das páginas).

( ) Os textos que fazem parte do LD.

( ) Os exercícios de leitura e escrita.

( ) Os exercícios de áudio e produção oral.

( ) A gramática.

( ) O livro do professor.

( ) Adequação dos conteúdos por ano (currículo).

( ) Proposta do livro apresentada na introdução.

( ) Outros. Quais?

\section{Se você fez uma análise do LD que critérios você observou?}

Relação entre texto e exercício

As possibilidades de aplicação Adequação dos conteúdos aos alunos

Proposta do LD

Adequação dos conteúdos por ano

Exercícios de áudio e produção oral

O livro do professor

A gramática

Projeto Gráfico

Exercícios de leitura e escrita

Textos que fazem parte do LD

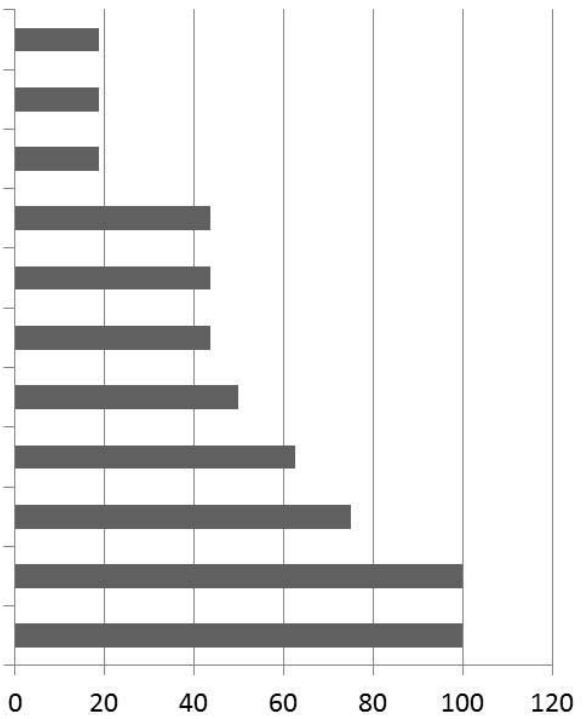

Figura 13. Critérios usados na análise do $L D^{15}$

${ }^{15}$ Nesse caso foi utilizado o gráfico de barras, pois a pergunta era de múltipla escolha. Assim, a soma das respostas seria maior que $100 \%$. 
Três professores marcaram a opção "outros", e os critérios usados são "adequação dos conteúdos ao nível dos meus alunos" (P33), "as possibilidades e sua efetiva aplicação (se útil ou confuso demais para o aluno)" (P39), "relação entre texto e exercício, se estão conectados e são coerentes" (P310).

Os critérios de análise que mais professores salientaram ter observado foram os textos e os exercícios de leitura e escrita. P310 relata que "a relação entre estes exercícios tem que ser conectada e coerente". Esses critérios também já haviam sido mencionados na seleção do LD do primeiro PNLD/LEM. O terceiro critério mais frequente é o projeto gráfico do $\mathrm{LD}$, novamente semelhante aos dados de 2011. Com relação à primeira edição, alguns dos professores afirmaram ter usado "a gramática" como critério para análise do $\mathrm{LD}$, por isso esta foi incluída como uma das opções neste questionário. É possível que a seleção do critério "gramática" se relacione com o que o P33 comentou na resposta "outros", pois afirma que os conteúdos devem ser adequados ao nível dos seus alunos. P39 mencionou as possibilidades de efetiva aplicação do LD (se útil ou confuso demais para o aluno). O critério "livro do professor" foi observado por metade dos professores. Esse critério e a "proposta do LD apresentada na introdução" são apresentados por Borges (2003) como relevantes para que os professores selecionem um LD que vá ao encontro da metodologia adotada em sua prática. O critério "análise da proposta do LD" foi adotado por sete professores. O critério "os exercícios de áudio e produção oral" também foi observado por sete docentes. Ressaltamos que muitos professores não utilizam o CD-ROM com os alunos (SARMENTO; SILVA, 2013), o que tornaria desnecessária uma seleção baseada nesse critério. Sete professores ainda observaram o critério "adequação dos conteúdos por ano (currículo)". Nesse sentido, P34 sugere que o MEC deveria 
analisar os conteúdos de cada ano ( $6^{o}, 7^{\circ}, 8^{o}$ e $\left.9^{o}\right)$ para programar o livro didático de acordo com o plano de estudo (de forma geral), pois muitas vezes é difícil usar o livro didático quando no plano de estudos não há relação com os conteúdos mostrados no livro.

Esse comentário é interessante, pois mostra o desconhecimento desse professor quanto à inexistência de um plano de estudos ou uma lista de conteúdos, comum a todo o Brasil. ${ }^{16}$ Assim, sendo o PNLD uma política nacional, seria impossível abranger os planos de estudos de todos os estados, municípios e escolas. No próprio Rio Grande do Sul não há qualquer diretriz curricular que determine uma lista de conteúdos. O documento vigente são os Referenciais Curriculares (RGS, 2009), que sugerem o ensino de línguas por intermédio de projetos pedagógicos baseados em gêneros em uma perspectiva bakhtiniana.

Podemos notar que critérios como "possibilidades de aplicação" e "adequação dos conteúdos aos alunos", que seriam relevantes para uma avaliação profunda, ficaram em segundo plano entre os critérios utilizados pelos participantes.

10. Sobre o Guia do Livro Didático, que está disponível on-line, de que forma você o utilizou no processo da escolha?

( ) Não utilizei o Guia do Livro Didático.

( ) Na íntegra.

( ) Apenas as resenhas de cada LD.

( ) Apenas a tabela comparativa entre cada coleção.

( ) Apenas os critérios da ficha de avaliação (p. 44).

${ }^{16}$ Neste momento, novembro de 2015, uma Base Nacional Comum para os Ensinos Fundamental e Médio está sendo discutida. Ver: $<$ http://basenacionalcomum.mec.gov.br/\#/site/inicio $>$. 


\section{Sobre o Guia do Livro Didático que está disponível online, de que forma você o utilizou no processo da escolha?}

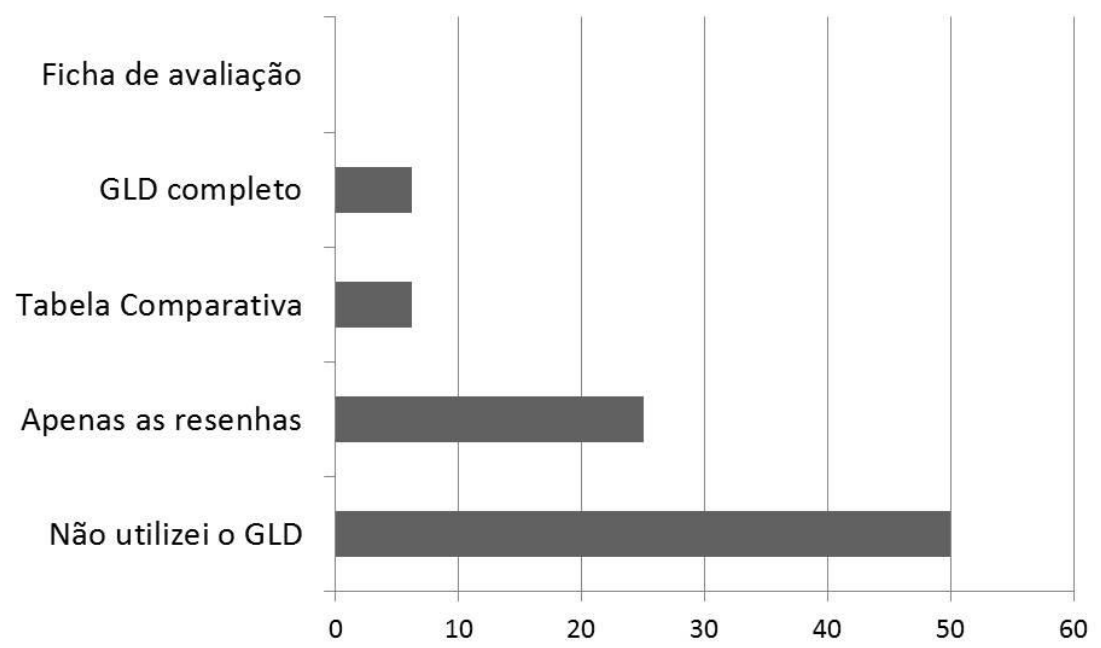

Figura 14. Utilização do Guia do Livro Didático

Dois professores não responderam a esta pergunta. Nossa intenção em perguntar sobre o uso do Guia foi, primeiro, averiguar a importância do GLD no processo de escolha e, segundo, observar se os professores questionados seguiam os mesmos critérios que os professores pesquisados por Borges (2003). Os professores entrevistados por este pesquisador analisaram majoritariamente as informações gráficas presentes no GLD; em menor frequência observaram as resenhas; e raramente leram o GLD de forma completa. Contudo, entre os participantes desta pesquisa, metade não utilizou o GLD. Apenas P31 declara ter utilizado todo o GLD, mas não recebeu o LD escolhido. Quatro professores leram apenas as resenhas de cada $\mathrm{LD}$, e um professor observou somente a tabela comparativa entre 
as coleções. É possível concluir que entre os professores que afirmam ter utilizado o GLD a maioria se assemelha aos dados obtidos por Borges (2003). Com base nessas respostas podemos observar também que o GLD não tem sido utilizado como proposto nos textos oficiais, o que pode ser ocasionado pelo desconhecimento da existência ou do teor do GLD, como apontado em alguns comentários (P315 e P311).

\section{Sugestões/comentários:}

\section{Quadro 5. Sugestões e comentários}

Sobre a escolha do LD na escola
Infelizmente na minha escola o processo de escolha esteve longe de ser transparente. Senti falta de alguns esclarecimentos fornecidos não apenas aos professores, mas também a toda a equipe envolvida no processo de escolha dos LDs.

De todas as disciplinas que fizeram sua escolha, apenas uma foi contemplada, e os envolvidos na finalização do processo (envio dos códigos das coleções selecionadas) não foram capazes de dar esclarecimentos satisfatórios. O resultado foi o recebimento de uma quantidade ínfima de livros, de coleções de baixa qualidade, que serão subutilizados ou mesmo desprezados pelos professores, em um claro desperdício de dinheiro público. Ratificando minha sugestão, é preciso que o processo de escolha seja extremamente transparente do início ao fim. (P31)

A direção e a coordenação das escolas devem manter os professores informados sobre a escolha do LD e fazer reuniões. (P36)

Penso que o aluno deve levar o livro para casa. Porém, já me perguntaram na escola o seguinte: ok, você deu o livro para eles, então como será no ano que vem? Pois as escolas recebem os livros de três em três anos. Penso que a escola deveria receber os livros todos os anos e em número suficiente para cada ano. (P38) 


\begin{tabular}{|c|c|}
\hline & $\begin{array}{l}\text { A supervisão da minha escola não informou sobre o Guia } \\
\text { do Livro Didático. O sistema de divulgação e escolha } \\
\text { poderia ser melhorado. Há colegas de outras áreas que não } \\
\text { usam o LD, o que pode ter banalizado o processo de } \\
\text { escolha. (P311) }\end{array}$ \\
\hline & $\begin{array}{l}\text { Não tinha conhecimento do Guia até entrar para o curso de } \\
\text { formação de professores (UFRGS), certamente o levarei em } \\
\text { consideração nas próximas escolhas. (P315) }\end{array}$ \\
\hline \multirow[t]{2}{*}{$\begin{array}{l}\text { Produção do } \\
\text { LD pelo PNLD }\end{array}$} & $\begin{array}{l}\text { Analisar os conteúdos de cada ano }\left(6^{\circ}, 7^{-}, 8^{\circ} \text { e } 9^{-}\right) \text {para } \\
\text { programar o livro didático de acordo com o plano de estudo } \\
\text { (de forma geral), pois muitas vezes é difícil usar o livro } \\
\text { didático quando no plano de estudos não há relação com os } \\
\text { conteúdos mostrados no livro. (P34) }\end{array}$ \\
\hline & $\begin{array}{l}\text { Adequar o texto com o nível de conhecimento do aluno na } \\
\text { realidade da escola pública. Dos livros atuais apenas } \\
\text { trabalho alguns textos. (P310) }\end{array}$ \\
\hline $\begin{array}{l}\text { Formação dos } \\
\text { professores } \\
\text { para usar o LD }\end{array}$ & $\begin{array}{l}\text { Esta sugestão é para o MEC: sugiro que além de oferecer o } \\
\text { livro didático sejam oferecidos cursos que ensinem o } \\
\text { professor a dinamizar seu uso, o que não se aprende nos } \\
\text { cursos de Letras. (P33) }\end{array}$ \\
\hline \multirow{2}{*}{$\begin{array}{l}\text { Logística do } \\
\text { PNLD }\end{array}$} & $\begin{array}{l}\text { Ainda não estou utilizando os livros didáticos, pois as } \\
\text { quantidades que foram enviadas para a escola são menores } \\
\text { que o número de alunos. A supervisora já tentou contato } \\
\text { com o Siscort, mas sem sucesso. (P35) }\end{array}$ \\
\hline & $\begin{array}{l}\text { O MEC deve observar o número de alunos de CADA } \\
\text { língua, pois o que acontece é que todos os anos nós } \\
\text { recebemos apenas METADE dos livros que precisamos e } \\
\text { ficamos com sobra de livros do } 9^{\circ} \text { ano. (P316) }\end{array}$ \\
\hline
\end{tabular}

Percebe-se pelos comentários que as regras do PNLD/LEM ainda não estão claras, apesar de já estarmos na segunda edição. Por exemplo, P31 não sabia da possibilidade de receber a segunda opção de LDs. Alguns professores (P36, P311 e P315) relatam que a coordenação ou direção da escola não os informou sobre a seleção do LD, ou não tinham conhecimento sobre o GLD no momento da escolha. P38 relata que tanto ele como a escola desconhecem que os LDs do PNLD/LEM são 
consumíveis, portanto desconhecem que receberão novos LDs anualmente. Entretanto, apesar do desconhecimento, o professor seguiu a recomendação do PNLD/LEM, entregando o LD aos alunos, acreditando que isso fosse contra a proposta do Programa.

Outra sugestão fornecida por P34 e P310, já discutida aqui, seria adequar os conteúdos por LD de acordo com um plano de estudos comum a todo o Brasil e adequar o nível do LD ao nível do aluno de escola pública. Em Sarmento e Silva (2013) apresentamos algumas soluções encontradas por professores de diferentes escolas para trabalhar com os LDs cujos conteúdos são considerados mais avançados do que o nível dos alunos, como, por exemplo, utilizar o LD do ano anterior. ${ }^{17}$

P33 sugere que o MEC ofereça formação aos professores sobre como usar o LD, pois, como aponta, há uma defasagem no curso de Letras com relação a esse aspecto. Essa mesma sugestão já foi dada por Batista (2003) ao se referir aos motivos da escolha do LD "não recomendado" ${ }^{18 "}$ pela maioria dos professores. Cabe ressaltar que já existem iniciativas de formação continuada de professores, como o curso em que foi realizado este questionário. Por fim, P35 e P316 reportam a falta de LDs suficientes para todos os alunos. Esse problema foi encontrado também nos dados sobre o PNLD/LEM de 2011 (SARMENTO; SILVA, 2013; 2014).

Pontos de destaque revelados por este questionário são: o fato de a maioria dos professores não estar fazendo uso do GLD como auxílio da escolha. Em segundo lugar, o desconhecimento ainda existente acerca do funcionamento do PNLD/LEM, apresentado nos comentários, como o desconhecimento da existência do GLD, ou de que o PNLD/LEM é consumível.

\footnotetext{
${ }^{17}$ Utilizar o livro do $6^{\circ}$ ano com o $7^{\circ}$,e assim por diante.

${ }^{18} \mathrm{Em}$ edições anteriores, mesmo os livros não recomendados poderiam ser escolhidos pelas escolas. Nas edições atuais os livros precisam ser efetivamente aprovados para poderem estar entre as opções.
} 


\section{Considerações Finais}

O objetivo principal desta pesquisa foi investigar como está ocorrendo a escolha do LD do PNLD/LEM pelos professores das escolas públicas. A partir dessa questão principal foram a) analisados questionários de 2011 relativos à escolha do LD do PNLD/LEM 2011; b) realizados questionários relativos à escolha do LD do PNLD/LEM 2014. As perguntas de pesquisa serão retomadas a seguir para que, com base nos dados, possam ser respondidas.

a) Os professores fazem uso do GLD para a escolha do $\mathrm{LD}$ ? Se sim, de que forma este uso se dá? Se não, outros elementos os auxiliam a escolher o LD?

Com base nos dados aqui apresentados podemos perceber que os professores, de forma geral, não fazem uso do GLD na seleção do LD. Aqueles que afirmaram utilizar o GLD consultam apenas as resenhas, não fazendo uso da ficha de avaliação, que poderia auxiliar a realização de uma seleção profunda (CUNNINGSWORTH, 1995). Além disso, observamos que o principal elemento a auxiliar os professores na escolha é o próprio LD enviado pelas editoras às escolas, demonstrando uma reconfiguração do PNLD nos seus contextos de prática (BOWE et al., 1992), uma vez que a proposta do Programa é que o GLD seja o principal auxílio dos professores para a coleção.

b) Os professores participam de reuniões com auxílio da coordenação pedagógica para escolha do LD?

O GLD (BRASIL, 2013a) sugere que sejam realizadas reuniões pedagógicas na escola para a seleção do LD. Cunningsworth (1995) salienta também que a seleção deve ser vista como um trabalho conjunto, contudo não é isso que os 
professores reportam nas respostas ao questionário. Poucos professores relatam, por intermédio dos questionários, ter participado de reuniões pedagógicas para este fim. No caso do PNLD, os professores poderiam discutir a seleção do LD ainda com colegas de outras áreas, se entendermos ser o trabalho escolar eminentemente interdisciplinar e que os LDs deveriam se aproximar, como um todo, do Projeto Político Pedagógico das escolas.

c) A experiência de já ter usado o LD do PNLD/LEM de 2011 contribuiu de alguma forma para a seleção do PNLD/LEM 2014?

Segundo os professores que participaram da pesquisa, a experiência de já ter utilizado o LD os auxiliou na seleção do PNLD/LEM de 2014, especificamente comparando os exercícios e as atividades que deram certo no LD do PNLD/LEM de 2011. Os professores ainda apontam como um problema o fato de não poderem escolher a mesma coleção que já estava em uso. ${ }^{19}$

d) Os professores têm acesso aos LDs para análise? Se sim, como esta se dá?

Por intermédio dos questionários, percebe-se que a maioria dos professores teve acesso a pelo menos uma coleção dos LDs selecionados. Também podemos verificar que são as editoras que procuram as escolas para divulgar seus LDs, e não as escolas que procuram as editoras (pergunta oito). A maioria dos professores observou critérios como os textos presentes no LD e o projeto gráfico, deixando para segundo plano critérios como as possibilidades de aplicação do LD em sala de aula e a proposta (expressa na introdução dos livros) do LD. Metade dos professores também não observou a proposta das coleções

19 As coleções aprovadas no PNLD 2011, ou seja, na primeira edição, não constavam entre as obras aprovadas da segunda edição. 
didáticas, incorrendo nas mesmas práticas apresentadas pelos professores investigados por Tagliani (2009) e Ramos (2010).

Este estudo está em consonância com a visão de que uma política não é simplesmente recebida e implementada nas suas arenas, mas é interpretada e, então, recriada (BOWE; BALL; GOLD, 1992). Se analisássemos somente o GLD e o tomássemos como a prática, teríamos uma leitura equivocada sobre o que está efetivamente acontecendo entre os professores pesquisados, que estão utilizando mecanismos diferentes daqueles preconizados nos textos oficiais do PNLD para realizar a escolha da coleção didática. Com base nos dados analisados, conclui-se que são os materiais de divulgação enviados pelas editoras que estão auxiliando os professores na escolha. Dessa forma, os professores acabam sendo influenciados pelo material recebido da editora, e não pela análise presente no GLD. Como foi mostrado, os professores que receberam apenas a divulgação de uma coleção a escolheram. Destarte, mesmo sendo a segunda edição do PNLD/LEM, ainda existe desconhecimento acerca dos documentos e, consequentemente, das diretrizes dessa política por professores e outros envolvidos com o LD na escola.

Nesse sentido, devido à importância que o PNLD pode ter no cenário escolar, acreditamos que uma grande campanha de divulgação deveria ser feita nas diferentes mídias em momentoschave de cada ciclo trienal do PNLD. O momento da escolha é crucial e não poderia ficar sujeito quase unicamente ao trabalho das editoras. O GLD é um instrumento importante para auxiliar professores neste processo, mas não parece estar cumprindo seu papel. É importante lembrar que a rotina de professores e gestores escolares é demasiadamente pesada, com muitos documentos, muitos programas e muitas políticas acontecendo simultaneamente. Em vista dessa realidade, torna-se papel dos órgãos governamentais alertar as escolas e seus participantes sobre processos importantes, mas não por intermédio de mais documentos, pois os já existentes são suficientes. Esse alerta 
pode vir por meio de chamadas de rádio, televisão e mídias sociais, por exemplo, de forma que seja assegurado um processo de escolha transparente e consciente que reflita os anseios e as necessidades da sociedade como um todo.

\section{Referências}

ALFERES, Márcia Aparecida; MAINARDES, Jefferson. Formação continuada de professores alfabetizadores: uma avaliação do Programa Pró-Letramento. Meta: Avaliação, Rio de Janeiro, v. 4, n. 10, p. 1, 27 jan./abr. 2012. Disponível em: $<$ http://metaavaliacao.cesgranrio.org.br/index.php/metaavaliacao /article/view/97>. Acesso em: 19 abr. 2014.

ALVIM, Yara Cristina. A avaliação do livro didático de história: diálogos entre pareceristas e professores à luz dos Guias de Livros Didáticos do PNLD. SIMPÓSIO NACIONAL DE HISTÓRIA, XXV, Anais... Fortaleza, p. 9211-9221, jun. 2009. Disponível em:

<http://anpuh.org/anais/wp-content/uploads/ANPUH.S25.pdf>. Acesso em: 3 fev. 2014.

BOWE, Richard; BALL, Stephen J.; GOLD, Anne. Reforming education \& changing schools: case studies in policy sociology. London: Routledge, 1992.

BATISTA, Antônio Augusto Gomes. A avaliação dos livros didáticos: para entender o Programa Nacional do Livro Didático (PNLD). In: BATISTA, Antônio Augusto Gomes; ROJO, Roxane (Org.). Livro didático de língua portuguesa, letramento e cultura da escrita. Campinas: Mercado de Letras, 2003. p. 2568. 
A escolha do livro didático de língua estrangeira...

BORGES, Cristina. O Guia dos Livros Didáticos: como se comporta o professor? Revista Partes, São Paulo, ano III, n. 34, jun. 2003. Disponível em:

<http://www.partes.com.br/ed34/emquestao.asp>. Acesso em: 3 fev. 2014.

BRASIL. Edital de Convocação para Inscrição no Processo de Avaliação e Seleção de Coleções Didáticas para o Programa Nacional do Livro Didático (PNLD) 2014. MEC, 2018. Disponível em: <http://www.fnde.gov.br/programas/livrodidatico/livro-didatico-editais>. Acesso em: 8 abr. 2014.

- Edital de Convocação para o Processo de Inscrição e Avaliação de Coleções Didáticas para o Programa Nacional do Livro Didático (PNLD) 2014. MEC, 2011. Disponível em: <http://www.fnde.gov.br/programas/livro-didatico/livrodidatico-editais>. Acesso em: 3 mar. 2014.

- Guia de Livros Didáticos PNLD 2014: Língua Estrangeira Moderna. Brasília: MEC, 2013a. Disponível em: <http://www.fnde.gov.br/arquivos/category/125guias?download=8322:livro-linguaestrangeira>. Acesso em: 03 Fev. 2014.

. Orientações para o Registro da Escolha do PNLD 2014 $6^{\underline{o}}$ ao $9^{\underline{o}}$ ano do Ensino Fundamental. MEC, 2013b. Disponível em: <http://www.fnde.gov.br/programas/livro-didatico/guias-dopnld/item/4661-guia-pnld-2014>. Acesso em: 3 fev. 2014.

CASSIANO, Célia Cristina de Figueiredo. O mercado do livro didático no Brasil: da criação do Programa Nacional do Livro Didático (PNLD) à entrada do capital internacional espanhol (1985-2007). 2007, 252f. Tese (Doutorado em Educação: 
História, Política e Sociedade) - Instituto de Educação, PUC-SP, São Paulo, SP.

CUNNINGSWORTH, Alan. Choosing your coursebook. Londres: Heinemann, 1995.

MAINARDES, Jefferson. Abordagem do Ciclo de Políticas: uma contribuição para a análise de políticas educacionais. Educação e Sociedade, Campinas, v. 27, n. 94, p. 47-69. 2006. Disponível em: <http://www.scielo.br/pdf/es/v27n94/a03v27n94.pdf>. Acesso em: 19 abr. 2014.

RAMOS, Rosinda de Castro Guerra. Um olhar avaliativo para o módulo fundamentos para a avaliação e preparação de material didático. In: CELANI, Maria Antonieta Alba (Org.). Reflexões e ações (trans)formadoras no ensino-aprendizagem de Inglês. Campinas: Mercado de Letras, 2010. p. 57-72.

SARMENTO, Simone; SILVA, Larissa Goulart; A reconfiguração do Programa Nacional do Livro Didático de Língua Estrangeira pelos atores sociais. CONGRESSO BRASILEIRO DE LINGUÍSTICA APLICADA, 10. Anais... Rio de Janeiro, v. 2, n. 1, p. 1-21, 2013. Disponível em: <http://www.alab.org.br/images/stories/alab/CBLA/ANAIS2013/ sarmento-e-silva.pdf>. Acesso em: 3 fev. 2014.

SARMENTO, Simone; SILVA, Larissa Goulart; The Book is (not) on the table: o Programa Nacional do Livro Didático no cotidiano escolar da educação linguística. CONGRESSO BRASILEIRO DE LINGUÍSTICA APLICADA, 9. Anais... Rio de Janeiro, v. 1, n. 1, p. 1-16, 2012. Disponível em: <http://www.alab.org.br/images/stories/alab/CBLA/ANAIS/tema s/24_12.pdf> . Acesso em: 29 Jun. 2014. 
A escolha do livro didático de língua estrangeira...

SCHLATTER, Margarete; GARCEZ, Pedro. Línguas adicionais (espanhol e inglês). Referenciais curriculares do Estado do Rio Grande do Sul: linguagens, códigos e suas tecnologias. Porto Alegre: Secretaria de Estado da Educação, Departamento Pedagógico, v. 1, p. 127-172. 2009. Disponível em: <http://www.educacao.rs.gov.br/dados/refer_curric_voll.pdf $>$. Acesso em: 29 jun. 2014.

TAGLIANI, Dulce Cassol. O processo de escolha do livro didático de língua portuguesa. Linguagem em (Dis)curso, Palhoça, v. 9, n. 2, p. 303-320, maio/ago. 2009. Disponível em: $<$ http://linguagem.unisul.br/paginas/ensino/pos/linguagem/0902/ 090204.pdf>. Acesso em: 3 fev. 2014.

Submetido em: 17/06/2015 Aceito em: 27/10/2015

Title: Choosing a foreign language coursebook from the Brazilian National Program for Coursebooks 